DOI https: / / doi.org/10.32837/yuv.v0i5.2005

\author{
М. Михайлів, \\ кандидат юридичних наук, доцент, \\ доцент кафедри цивільного права та процесу \\ Львівського національного університету імені Івана Франка
}

\title{
ПРОБЛЕМИ У СФЕРІ ПРАВОВОГО РЕГУЛЮВАННЯ СПАДКУВАННЯ ЗА ЗАКОНОМ: ЦИВІЛЬНО- ПРАВОВІ АСПЕКТИ
}

Важливе місце серед інститутів цивільного права належить спадковому праву. Після ухвалення Цивільного кодексу (далі - ЦК України) у 2003 р. в цивільному праві України задекларовано нові підходи до переходу прав і обов'язків від спадкодавця до спадкоємців. Зокрема це пов'язано 3 розширенням кола спадкоємців за законом, зміною розміру обов'язкової частки в разі спадкування за заповітом, закріпленням нових механізмів спадкування прав на окремі види об'єктів, новими підходами до класифікації заповітів тощо. Проте розвиток суспільних відносин, удосконалення речових прав зумовили необхідність з'ясування правової природи й особливостей спадкування. Насамперед це стосується сфери спадкування за законом.

Мета проведеного дослідження зробити аналіз змісту норм цивільного законодавства у сфері спадкування за законом; визначити поняття спадкування за законом та провести аналіз змісту даного поняття; виокремити проблеми у сфері правового регулювання спадкування за законом, запропонувати шляхи їх вирішення.

Питанням спадкування за законом приділяли увагу низка українських та іноземних учених, серед яких: В.В. Валах, Г.В. Галущенко, Ю.О. Заіка, О.О. Кармаза, В.І. Кисіль, О.Є. Кухарєв, В.І. Крат, Л.А. Лунц, 3.B. Ромовська, А.А. Рубанов, H.O. Саніахметова, I.B. Спасибо-
Фатєєва, А.А. Степанюк, В.Л. Толстих, С.Я. Фурса, Є.О. Харитонов та інші. Проте в науці ще залишається чимало питань, які потребують дослідження та $є$ актуальними.

Одним із видів спадкування, виходячи зі змісту ст. 1217 ЦК України, $є$ спадкування за законом. Спадкуванню за законом присвячено ст. ст. 1258-1267 гл. 86 ЦК України. Спадкування за законом, на відміну від спадкування за заповітом, яке здійснюється на підставі волевиявлення заповідача, відбувається за закріпленою законодавцем моделлю спадкування. Воно здійснюється почергово з урахуванням родинних, сімейних, квазіродинних відносин або ж відносин щодо утримання.

На думку B.I. Крат, модель спадкування за законом формується за допомогою встановлення великої кількості винятків із загальних правил. $\mathrm{y}$ зв'язку із чим науковець виділяє загальні та спеціальні правила, що встановлюються до спадкування за законом. До загальних правил відноситься те, що: спадкоємцями можуть бути лише фізичні особи; перелік потенційних спадкоємців за законом вичерпно встановлений у гл. 86 ЦК України шляхом зазначення відповідних категорій фізичних осіб або ж шляхом закріплення критеріїв для ї визначення; спадкування відбувається зазвичай у порядку, установленому законом почергово; існують можливості спадкування за законом 
і за заповітом. До спеціальних правил спадкування за законом належать: зміна черговості (на основі договору або рішення суду); внутрішня черговість у межах п'ятої черги; право представлення; відмова спадкоємця від прийняття спадщини на користь іншого спадкоємця; спадкова трансмісія [13, с. 475-476].

Варто зазначити, що ні старий Цивільний кодекс Української Радянської Соціалістичної Республіки 1963 р., ні новий ЦК України 2003 р. не містять визначення поняття спадкування за законом, що, у свою чергу, ускладнює розуміння змісту таких відносин. У зв'язку із цим під спадкуванням за законом пропонуємо розуміти спосіб здійснення права на спадкування, відповідно до якого відбувається перехід спадщини в порядку черговості від спадкодавця до фізичних осіб, які є кровними родичами спадкодавця, а також до інших осіб, які відповідно до закону наділені правом на спадкування за законом.

Одним із недоліків гл. 86 ЦК України є відсутність спеціальної норми, яка б передбачала, у яких випадках фізична особа - спадкоємець за законом наділяється правом здійснення спадкування за законом. Проте ст. 1223 ЦК України передбачає, що таке право виникає у спадкоємців у день відкриття спадщини. Право на спадкування мають особи, визначені в заповіті. У разі відсутності заповіту, визнання його недійсним, неприйняття спадщини або відмови від їі прийняття спадкоємцями за заповітом, а також у разі неохоплення заповітом усієї спадщини право на спадкування за законом одержують особи, визначені у ст. ст. 1261-1265 цього Кодексу.

Уважаємо не зовсім коректною ч. 2 ст. 1223 ЦК України, у якій зазначено випадки, за наявності яких спадкоємці за законом одержують право на спадкування, оскільки ця частина суперечить ч. 3 цієї статті, у якій зазначено, що право на спадку- вання виникає в день відкриття спадщини. У зв'язку із цим уважаємо, що як у спадкоємців за заповітом, так i y спадкоємців за законом право на спадкування виникає на підставі такого юридичного факту, як смерть фізичної особи або оголошення іï померлою, виникає в день відкриття спадщини. А здійснювати своє справо на спадкування за заповітом чи за законом спадкоємці можуть лише за наявності певних обставин. Зокрема, здійснювати право на спадкування за заповітом спадкоємці можуть у разі наявності чинного заповіту. Можливість здійснення права на спадкування спадкоємцями за законом виникає за наявності таких підстав, як: відсутність заповіту; визнання заповіту повністю або в частині недійсним; неохоплення заповітом усієї сукупності спадщини; відмова від прийняття спадщини спадкоємцями за заповітом; усунення від прийняття спадщини у випадках, встановлених законом.

У зв'язку із цим пропонується внести зміни до ст. 1223 ЦК України та викласти ї в такій редакції:

«Ст. 1223. Право на спадкування

1. Право на спадкування виникає у день відкриття спадщини.

2. Право на спадкування мають особи, визначені в заповіті.

3. У випадках, встановлених законом, право на спадкування мають особи, визначені у ст. ст. 1261-1265 цього Кодексу.

4. Здійснення права на спадкування спадкоємцями за заповітом та за законом відбувається в порядку, встановленому ЦК України».

У зв'язку із цим також пропонуємо ст. 1258 гл. 86 ЦК України викласти в новій редакції:

«Ст. 1258. Здійснення права на спадкування за законом

1. Спадкування за законом здійснюється у випадках: відсутності заповіту; визнання заповіту повністю або в частині недійсним; неохоплення заповітом усієї сукупності спадщини; 
відмови від прийняття спадщини спадкоємцями за заповітом; усунення від прийняття спадщини у випадках, встановлених законом.

2. Спадкоємці за законом здійснюють право на спадкування почергово.

3. Кожна наступна черга спадкоємців за законом здійснює право на спадкування в разі відсутності спадкоємців попередньої черги, усунення їх від права на спадкування, неприйняття ними спадщини або відмови від ii прийняття, крім випадків, встановлених ст. 1259 цього Кодексу».

Також пропонується в усіх статтях гл. 86 ЦК України словосполучення «одержання права на спадкування спадкоємцями за законом» замінити на «здійснення права на спадкування спадкоємцями за законом». Внесення таких змін буде узгоджуватися зі ст. ст. 12, 13 та 1217 Цивільного кодексу України.

Одним із найбільш спірних питань у доктрині є визначення кола осіб, які будуть належати до спадкоємців за законом. Як зазначає Ю.О. Заіка, питання щодо того, якими критеріями має керуватися законодавець, коли визначає коло спадкоємців за законом, одне 3 найбільш спірних у цивілістичній літературі. Визначення кола осіб, які закликаються до спадкування за законом у випадках, коли спадкування за заповітом із фактичних чи юридичних причин неможливе, є головним змістом норм у разі спадкування за законом [5, с. 146].

На підставі аналізу гл. 86 ЦК України можемо виділити такі критерії, якими законодавець послуговується під час віднесення тих чи інших фізичних осіб до спадкоємців за законом:

- родинні відносини, які визначаються за ступенем споріднення зі спадкодавцем;

- сімейні відносини, які виникають на підставі реєстрації шлюбу із спадкодавцем або в разі спільного проживання зі спадкодавцем однією сім'єю не менш як п'ять років до часу відкриття спадщини;
- квазіродинні відносини, які виникають у зв'язку з усиновленням дитини спадкодавцем;

- відносини, пов'язані з утриманням, а саме утриманці спадкодавця, які не були членами його сім’”.

Проте, як убачається зі змісту ст. ст. 1261-1266 ЦК України, законодавець взяв за основу віднесення тих чи інших фізичних осіб у певну чергу критерій родинних відносин, а саме ступінь кровного споріднення. Отже, між спадкодавцем і спадкоємцями має існувати біологічний зв'язок кровного споріднення певного ступеня. Проте якщо 1-3 черги становлять фізичні особи, які $€$ кровними родичами, то до 4-5 черги, окрім осіб, пов'язаних родинними відносинами, включені особи, які пов'язані сімейними відносинами або відносинами піклування, а саме особи, які зі спадкодавцем проживають однією сім'єю не менше п'яти років до часу відкриття спадщини, й утриманці, які не були членами сім’і спадкодавця.

На відміну від ЦК України 2003 р., який виділяє п'ять черг спадкоємців, Цивільний кодекс Української Радянської Соціалістичної Республіки 1963 р. обмежував коло спадкоємців за законом родичами другого ступеня споріднення. Зокрема, в першу чергу спадкоємців за законом, відповідно до ст. 529 Цивільного кодексу Української Радянської Соціалістичної Республіки [15], відносилися діти (зокрема, усиновлені), дружина і батьки (усиновителі) померлого. До числа спадкоємців першої черги належить також дитина померлого, яка народилася після його смерті. Онуки і правнуки спадкодавця спадкували як спадкоємці за законом першої черги у випадку, якщо на час відкриття спадщини не було серед живих того з їхніх батьків, хто був би спадкоємцем. Відповідно до ст. 530 Цивільного кодексу Української Радянської Соціалістичної Республіки, до спадкоємців другої черги відносилися брати і сестри померлого, а також дід 
та баба померлого як з боку батька, так і з боку матері.

Про доцільність обмеження кількості черг та кола спадкоємців за законом висловлювалися чимало науковців, серед яких М.Я. Пергамент, А.А. Бугаєвський, Г.Ф. Шершеневич, Ю.О. Заіка й інші. Оскільки логічним видається, що спадкоємцями за законом повинні бути лише ті особи, які $€$ кровноспорідненими із спадкодавцем та найближчими особами, що пов'язані родинними відносинами.

Критерій кровного споріднення та найближчих родинних відносин став основою для формування черг спадкоємців за законом у Цивільних кодексах більшості європейських державах. Так, наприклад, у $\$ 730$ Цивільного кодексу Австрії [1] передбачено, що спадкоємцями за законом є один із подружжя й ті особи, які перебувають у родинних відносинах із спадкодавцем за найближчою лінією споріднення. Відповідно до § 731 виділяються чотири лінії спадкоємців за законом, які перебувають із спадкодавцем у родинних відносинах. Так, до першої належать спадкоємці, об'єднані зі спадкодавцем як їхнім предком, а саме його діти та їхні нащадки. До другої лінії відносяться мати і батько спадкодавця разом із тими, з ким спадкодавець об'єднаний матір'ю чи батьком, а саме брати, сестри і їні нащадки. До третьої лінії - баба і дід спадкодавця разом із сестрами і братами батьків спадкодавця та іхні нащадки. Як спадкоємці четвертої лінії допускаються до спадкування тільки прабаба i прадід спадкодавця. Законні права подружжя на спадкування регулюються \$\$ 757-759 Цивільного кодексу Австрії. Зокрема, подружжя наділене правом спадкувати поряд із лінією, яка закликається до спадкування. Визначення розміру спадкової частки подружжя залежатиме від черги, яка буде спадкувати за законом.

Подібний підхід можемо спостерігати і в цивільному законодавстві
Німеччини, Ізраїлю, інших європейських держав. Так, відповідно до §§ 1924-1928 Цивільного уложення Німеччини, спадкоємцями першої черги за законом $є$ нащадки спадкодавця (діти); у другу чергу спадкують батьки спадкодавця та їхня прямі нащадки; у третю чергу спадкують діди і баби спадкодавця та їхні нащадки; спадкоємцями четвертої черги за законом є прадіди і прабаби спадкодавця та їхні нащадки. Спадкоємцями п'ятої та наступних черг спадкоємців за законом відповідно до $\S 1929$ Цивільного уложення Німеччини $€$ далекі предки спадкодавця та їхні нащадки. Подружжя допускається як спадкоємець за законом поряд із родичами першої, другої чи інших черг і спадкує лише чітко визначену частку спадкового майна. Залежно від черги, з якою подружжя спадкує, така частка змінюється. У разі відсутності родичів 1-3 черг усе спадкове майно переходить до подружжя [3].

Відповідно до Закону від 1965 р. «Про спадкування» [2], в Ізраїлі спадкоємцями за законом є: особа, яка була чоловіком (дружиною) спадкодавця на момент його смерті; родичі спадкодавця, а саме діти спадкодавця та їхні нащадки, батьки спадкодавця та їні нащадки, діди і баби спадкодавця та їхні нащадки. Чоловік (дружина) спадкодавця спадкує поряд з особами, які закликаються до спадкування за законом, із виділенням частини спадщини, встановленої законом. Подібний підхід щодо черговості спадкування закріплено в цивільних кодексах та законах Іспаніі, Чехії, Японії, Китаю тощо.

Аналіз норм у сфері спадкування за законом окремих європейських держав вказує на те, що формування черг здійснювалося лише 3 урахуванням найближчих родинних відносин спадкодавця із спадкоємцями, а один із подружжя спадкодавця наділений статусом законного спадкоємця та спадкує разом із чергою, яка 
закликається до спадкування. Такий підхід. на нашу думку, є правильним та відповідає правовій природі спадкового правонаступництва.

3 урахуванням вищезазначеного, пропонуємо за основу формування черг спадкоємців взяти лише критерій родинних відносин і класифікацію здійснювати 3 урахуванням ступеня кровного споріднення. 3 кола спадкоємців п'ятої черги виключити утриманців спадкодавця, які не були членами його сім’і.

Пропонуємо виділяти два види спадкоємців за законом:

1) один із подружжя, який пережив спадкодавця; фізичні особи, які перебувають у родинних відносинах найближчого ступеня споріднення із спадкодавцем (право на спадкування здійснюють почергово);

2) інші фізичні особи, які у випадках, визначених законом, можуть отримати право на спадкування за законом. До цих осіб відносити: членів сім”і спадкодавця, усиновлених дітей, дітей, народжених способом (шляхом) штучного запліднення, дітей, народжених від сурогатної матері.

Правом на спадкування за законом наділений один із подружжя, який пережив спадкодавця. Подружжям визнаються особи, які перебувають у зареєстрованому шлюбі, що засвідчується свідоцтвом про шлюб. На підставі шлюбу створюється сім'я. Отже, шлюб є підставою для виникнення прав і обов'язків подружжя.

Не будуть мати права на спадкування за законом особи, шлюб між якими був розірваний або визнаний недійсним до моменту відкриття спадщини.

Невирішеними та неврегульованими натепер залишаються питання, пов'язані 3 такими спадкоємцями за законом, як діти спадкодавця, зокрема й зачаті за життя спадкодавця та народжені після його смерті, які відповідно до ст. 1261 ЦК України мають право на спадкування в першу чергу.
Виходячи зі змісту поняття сім’ї, на підставі аналізу норм розд. III гл. 12, розд. IV гл. 18 Сімейного кодексу України можемо виділити такі види дітей як спадкоємців першої черги:

- діти, народжені від батьків, які перебувають у зареєстрованому шлюбі (походження дитини від батьків визначається на підставі Свідоцтва про шлюб та документа закладу охорони здоров'я про народження дружиною дитини);

- діти, народжені від батьків, які не перебувають у зареєстрованому шлюбі (походження дитини від батька визначається за заявою матері та батька дитини або за рішенням суду);

- діти, народжені в результаті застосування допоміжних репродуктивних технологій (походження дитини визначається за записом про батька дитини);

- діти, народжені до спливу десяти місяців після припинення шлюбу або визнання його недійсним (відповідно до ч. 2 ст. 122 Сімейного кодексу України, походить від подружжя у випадках, встановлених законодавством, батьківство може бути визнане за рішенням суду);

- діти, усиновлені батьками або одним із батьків (прирівнюються до дітей усиновлювача 3 моменту набрання чинності рішення суду про усиновлення).

Законодавець у ч. 1 ст. 1222 ЦК України закріплює, що спадкоємцями за заповітом і за законом можуть бути фізичні особи, які $€$ живими на час відкриття спадщини, а також особи, які були зачаті за життя спадкодавця і народжені живими після відкриття спадщини [14]. Уважаємо, що така норма за своїм змістом суперечить ч. 1 ст. 2 та ст. ст. 24-26 ЦК України, оскільки суб'єктом права й учасником цивільних правовідносин (спадкових відносин) ми можемо вважати людину, яка наділена цивільною правоздатністю, що виникає в момент іï народження. Відповідно 
до ст. 6 Закону України «Про охорону дитинства», кожна дитина має право на життя 3 моменту визначення Піi живонародженою та життєздатною за критеріями Всесвітньої організації охорони здоров'я [9]. Поняття «живонародження» й ознаки дитини, народженої живою (новонароджена), передбачені Інструкцією 3 визначення критеріїв перинатального періоду живонародженості та мертвонародженості, затвердженої наказом Міністерства охорони здоров'я від 29 березня 2006 р. №179 [6].

У зв'язку із цим зачату, але ще не народжену дитину не можна визнавати суб'єктом права та вважати учасником як спадкових відносин зокрема, так і цивільних відносин загалом, а тому вона не може бути наділена суб'єктивними правами чи обов'язками.

Проте в п. 2 ч. 2 ст. 25 ЦК України зазначається, що у випадках, установлених законом, охороняються інтереси зачатої, але ще не народженої дитини. I, як слушно зазначає О.Є. Кухарєв, невипадково в законі йдеться саме про «інтереси» зачатої та ненародженої дитини, а не про іï права. До народження людини неможливо говорити про виникнення суб’єктивного права. Законодавець лише гарантує права майбутнього суб'єкта за умови народження живим [8, с. 44].

Неможливість наділення плода будь-якими суб'єктивними цивільними правами визначив Європейський суд 3 прав людини, який 8 липня 2004 р. постановив рішення у справі «Во проти Франції» [16], у якому чітко зазначив, що плід (ембріон) не наділений навіть найбільш важливим правом - правом на життя [11, c. 281].

Пропонуємо доповнити ЦК України статтею «Забезпечення інтересів потенційних спадкоємців у сфері спадкування за законом» такого змісту:

«Правом бути спадкоємцем першої черги можуть бути наділені потенційні спадкоємці.
Потенційними спадкоємцями за законом є діти спадкодавця, які зачаті за життя спадкодавця та народженні після його смерті.

Право на спадкування за законом у потенційних спадкоємців виникає з моменту їх народження.

Підставами для позбавлення права на спадкування за законом потенційних спадкоємців $€$ встановлення в судовому порядку факту, що спадкодавець не є батьком цієї дитини».

Також необхідно звернути увагу на правовий статус дітей, усиновлених спадкодавцем. Так, відповідно до ст. 207 Сімейного кодексу України, усиновленням $€$ прийняття усиновлювачем у свою сім'ю особи на правах дочки чи сина, що здійснене на підставі рішення суду, крім випадку, передбаченого ст. 282 цього Кодексу. Усиновлення дитини провадиться в іiі найвищих інтересах для забезпечення стабільних та гармонійних умов іi життя [12].

Відповідно до ст. 11 Європейської конвенції про усиновлення дітей від 27 листопада 2007 р., унаслідок усиновлення дитина стає повноправним членом сім'ї усиновлювача (усиновлювачів) і має стосовно усиновлювача (усиновлювачів) та його або їхньої сім'ї такі самі права й обов'язки, як і діти усиновлювача (усиновлювачів), батьківство яких установлено законом. Усиновлювач (усиновлювачі) мають батьківську відповідальність стосовно дитини. Усиновлення припиняє правові відносини між дитиною та іï батьком, матір'ю та сім'єю походження [4].

Відповідно до ч. 1 ст. 1260 ЦК України, у разі спадкування за законом усиновлений та його нащадки, з одного боку, та усиновлювач і його родичі - із другого, прирівнюються до родичів за походженням. Проте, виходячи із змісту ст. 11 Конвенції, усиновлена дитина набуває статусу члена сім'ї та у своїх правах прирівнюється до дітей усиновлювача. Отже, звідси можемо зробити висновок, що родинні 
відносини виникають лише у членів сім’ї усиновлювача, а не в усіх родичів усиновлювача. У зв'язку із цим пропонуємо ч. 1 ст. 1260 ЦК України доповнити та викласти в новій редакціï, зокрема:

«Право на спадкування внаслідок усиновлення особи (осіб) виникає 3 моменту здійснення усиновлення.

Усиновлені діти та їхні нащадки у сфері здійснення права на спадкування за законом прирівнюються до біологічних дітей спадкодавця та їхніх нащадків.

У разі спадкування за законом усиновлений та його нащадки, з одного боку, та усиновлювач і члени його сім’ $\dddot{i}$ - із другого, прирівнюються до родичів за походженням».

Чимало наукових дискусій пов'язано 3 можливістю надання права на спадкування за законом внукам за життя їхніх батьків. Так, на думку 3.В. Ромовської, визначений у законі спадково-правовий статус внуків несправедливий, у зв'язку із чим пропонує включити їх до другої черги спадкоємців за законом як самостійних фігурантів [10, с. 186-187]. Надання внукам спадкодавця права на спадкування обстоювали і такі вчені, як М.А. Єгорова, М.С. Абраменков, П.В. Чугунов та інші. Зважаючи на принцип справедливості та розумності як визначальні засади цивільного законодавства та враховуючи наявність між дідом (бабою) та внуком другого ступеня споріднення, пропозицію про внесення змін до другої черги спадкоємців за законом шляхом включення внуків спадкодавця було запропоновано й О.Є. Кухарєвим [7, с. 452].

Оскільки черги спадкоємців за законом сформовані, виходячи із критерію ступеня споріднення по прямій лініі, уважаємо, що включення внуків до другої черги спадкоємців за законом призведе до порушення послідовності визначення черговості спадкоємців, чим порушуватимуться права тих спадкоємців, які належать до третьої черги.
Спадкування за правом представлення $є$ різновидом спадкового правонаступництва, у зв'язку із чим внуки можуть спадкувати в разі смерті дітей спадкодавця до моменту відкриття спадщини. В інших випадках спадкують діти спадкодавця. Тому вважаємо логічною та правильною позицію законодавця, відповідно до якої внукам надане право спадкування за правом представлення.

Як підсумок можемо зазначити, що спадкування за законом $€$ важливим інститутом спадкового права, завданням якого $€$ визначення юридичної долі спадщини в разі відсутності волевиявлення спадкодавця. За допомогою норм цього інституту законодавець визначає коло спадкоємців, які наділяються правом спадкування за законом, визначається порядок закликання спадкоємців до спадкування та розподілу між ними спадкового майна. Проте з розвитком суспільних відносин в Україні, з урахуванням євроінтеграційних процесів правове регулювання спадкування за законом потребує оновлення. Удосконалення законодавства у сфері спадкування за законом допоможе вирішити чимало проблем, які виникають як у теорії спадкового права, так і в судовій практиці.

Cтаття присвячена дослідженню національного законодавства у сфері спадкування за законом і удосконаленню правового регулювання спадкування за законом в умовах новелізації Цивільного кодексу України. Звертається увага на те, що в національному законодавстві немае визначення поняття «спадкування за законом», що, як наслідок, ускладнюе розуміння змісту таких відносин. Запропоновано під спадкуванням за законом розуміти спосіб здійснення права на спадкування, відповідно до якого відбувається перехід спадщини в порядку черговості від спадкодавияя до фізичних осіб, які е кровними 
родичами спадкодавия, а також до інших осіб, які відповідно до закону наділені правом на спадкування за законом. У результаті проведеного аналізу норм цүивільного законодавства у сфері спадкування за законом звертається увага на доцільність заміни словосполучення «одержання права на спадкування спадкоємцями за законом» на «здійснення права на спадкування спадкоємиями за законом». У результаті проведеного аналізу норм Цивільного кодексу України та цивільного законодавства окремих іноземних держав щодо критерії формування черг спадкоємиів за законом звертається увага на те, що спадкоємиями за законом повинні бути лище ті особи, які $\epsilon$ кровноспорідненими із спадкодавцем та найближчими особами, що пов'язані родинними відносинами. У статті закцентовано увагу на тому, що ще не народжену дитину не можна визнавати суб'єктом права та вважати учасником як спадкових відносин зокрема, так i цивільних відносин загалом, а тому вона не може бути наділена суб'єктивними правами чи обов'язками. У зв'язку із изим запропоновано доповнити Цивільний кодекс України відповідною статтею, яка слугуватиме інструментом забезпечення інтересів потенційних спадкоємиів у сфері спадкування за законом. У статmі звернено увагу на правовий статус усиновлених дітей та потребу узгодити норми Цивільного кодексу України з Європейською конвенцією про усиновлення дітей. Як результат, удосконалення законодавства у сфері спадкування за законом допоможе вирішити чимало проблем, які виникають як у теорії спадкового права, так $і$ в судовій практиціi.

Ключові слова: спадкування, спадкування за законом, спадкодавець, спадкоємці, черги спадкування.
Mykhailiv M. Legal regulation of inheritance matters: civil law aspects

The article is devoted to the analysis of national legislation in the area of inheritance and the improvement of legal regulation of inheritance in the context of the novelization of the Civil Code of Ukraine.

A special attention is drawn to the fact that in Ukrainian national legislation there is no definition of the concept of inheritance by the provisions of law, which, as a result, makes it difficult to understand the very meaning of such relations.

It is proposed to understand the meaning of the inheritance by provisions of law as the way of realization of the right to inherit, according to which the inheritance is transferred in order of priority from the testator to individuals who are blood relatives of the testator, as well as to other persons who are legally entitled to inherit on the basis of law.

Having analyzed the norms of civil law in the area of inheritance by the provisions of law, special attention is drawn to the expediency of replacing the phrase "obtaining the right to inherit by heirs at law" to "realization of the right to inherit by heirs at law". As a result of the analysis of the norms of the Civil Code of Ukraine and the civil legislation of some foreign states on the criteria for forming the queues of heirs, it is pointed up that heirs by provisions of law should be only those persons who are blood relatives of the testator and close relatives. relations.

The article emphasizes that an unborn child cannot be recognized as a subject of law as well as considered as a participant in inheritance relations, in particular, and civil relations in general. Therefore, it cannot be endowed with subjective rights or responsibilities. In this regard, it is proposed to supplement the Civil Code of Ukraine with a relevant article, 
which will serve as a tool to ensure the interests of potential heirs in the area of legal inheritance.

The article draws attention to the legal status of adopted children and highlight the importance to align the provisions of the Civil Code of Ukraine with the European Convention on Adoption of Children. As a result, improving the law in the area of inheritance on the basis of law will help to tackle many problems that arise, both in the theory of inheritance law, and in judicial practice.

Key words: inheritance, inheritance on basis of law, testator, heirs, inheritance queues.

\section{Література}

1. Всеобщий гражданский кодекс Австрии. Пер. с нем. С.С. Маслова. Москва : Инфотропик Медиа, 2011. 272 c. ; Allgemeines Bbrgerliches Gesetzbuch (ABGB) JUSLINE Lsterreich.

2. Гражданское законодательство Израиля. Пер. с иврита. М.С. Хейфеи ; введ., сост., науч. ред. Н.Э. Лившии. Санкт-Петербург : Юридический иентр «ресс», 2003. 633 c.

3. Гражданское уложение Германии : Вводный закон $\kappa$ Гражданскому уложению $=$ Bbrgerliches Gesetzbuch Deutschlands mit Einfohrungsgesetz. Пер. с нем. В. Бергманн ; введ., сост., науч. ред. Т.Ф. Яковлева. 4-е изд., перераб. Москва: Инфотропик Медиа, 2015. 888 с. ; Німецьке иивільне уложення - Bbrgerliches Gesetzbuch. URL: https: / / www.gesetze-im-internet.de /bgb / BGB.pdf (дата звернення: 25.09.2020).

4. Європейська конвенція про усиновлення дітей від 27 листопада 2007 p. URL: https: / / zakon.rada.gov.ua/ laws/show/994_a17 (дата звернення: 25.09.2020)

5. Заіка Ю.О. Спадкове право в Украіні: становлення $i$ розвиток : монограрія. 2-е вид. Київ : КНТ, 2007. 288 c.

6. Інструкиія з визначення критеріїв перинатального періоду живонародже- ності та мертвонародженості, затв. наказом міністерства охорони здоров’я від 29 березня 2006 р. № 179. URL: https: / / zakon.rada.gov.ua/laws / show / z0427-06 (дата звернення: 25.09.2020).

7. Кухарєв O.Є. Теоретичні та практичні проблеми диспозитивності у спадковому праві : монографія. Київ : Алерта, 2019. 498 c.

8. Кухарєв о.Є. Актуальні питання спадкового права в судовій практищі : практичний посібник. Київ : Алерта, 2017. $260 \mathrm{c}$.

9. Про охорону дитинства: Закон України від 26 квітня 2001 р. № 2402-III. URL: https:/ / zakon.rada.gov.ua/laws / show/2402-14 (дата звернення: 25.09.2020)

10. Ромовська 3.В. Українське цивільне право. Спадкове право : підручник. Київ : Aлерта ; КНТ ; ЦУЛ, 2009. 264 с.

11. Стефаниук P.О. Особисті немайнові права фізичних осіб у цивільному праві (поняття, зміст, система, особливості здійснення та захисту) : монографія. Хмельницький, 2007. 626 с.

12. Сімейний кодекс Украӥни : закон від 10 січня 2002 p. № 2947-III. URL: https: / / zakon.rada.gov.ua/laws / show/2947-14\#Text (дата звернення: 25.09.2020)

13. Харьковская цивилистическая школа: грани наследственного права: монография / И.В. Спасибо-Фатеева и др. ; под ред. И.В. Спасибо-Фатеевой. Харьков: Право, 2016. 608 с.

14. Цивільний кодекс України : Закон від 16 січня 2003 р. № 435-IV. URL: https://zakon.rada.gov.ua/laws / show/435-15 (дата звернення: 25.09.2020).

15. Цивільний кодекс УРСР : Закон від 18 липня 1963 p. № 1540-VI (втратив чинність). URL: https:// zakon.rada.gov.ua / laws / show / 1540-06 (дата звернення: 25.09.2020).

16. Case of Vo v. France Application № 53924/00, July, 8, 2004. URL: https: / / www.worldlii.org / eu / cases / ECHR/2004/326.htlm (дата звернення: 25.09.2020) 